\title{
IMPACT OF $\mathrm{Er}^{3+}$ CONCENTRATION ON LUMINESCENCE IN NaLaF 4
}

\author{
J. Grube, A. Sarakovskis, G. Doke, M. Springis \\ Institute of Solid State Physics, \\ University of Latvia, \\ 8 Kengaraga Str., LV-1063, Riga, LATVIA \\ e-mail: jurgis.grube@cfi.lu.lv
}

\begin{abstract}
In this work, $\mathrm{NaLaF}_{4}$ doped with $\mathrm{Er}^{3+}$ of different concentrations was synthesized. The luminescence spectrum for $\mathrm{NaLaF}_{4}: \mathrm{Er}^{3+}(0.2 \mathrm{~mol} \%)$ at 489 $\mathrm{nm}$ excitation reveals characteristic $\mathrm{Er}^{3+}$ luminescence bands in the green $(540 \mathrm{~nm})$, red $(660 \mathrm{~nm})$ and infrared $(980 \mathrm{~nm})$ spectral regions. The green luminescence band originated from the ${ }^{4} \mathrm{~S}_{3 / 2} \rightarrow{ }^{4} \mathrm{I}_{15 / 2}$ transition is the most intensive one in the luminescence spectrum. As the concentration of the activator is increasing, the intensity of all luminescence bands changes significantly. The super-linear increase of the infrared luminescence intensity with increasing $\mathrm{Er}^{3+}$ concentration as well as the quenching of green luminescence at the concentrations exceeding $2 \mathrm{~mol} \%$ can be attributed to the cross-relaxation process between the activator ions.
\end{abstract}

Keywords: erbium; luminescence; cross-relaxation.

\section{INTRODUCTION}

For several decades, the attention of scientists has been attracted to upconversion (UC) processes related to absorption of several light photons (usually infrared (IR)) followed by emission of light in the visible or even ultraviolet spectral regions [1]. The UC effect could be used in different areas like solid state lasers [2], temperature sensors [3], multicolor and white light simulation [4, 5], improvement of the efficiency of solar cells [6] and others.

Although UC luminescence is observable in materials doped with various transition metal and rare-earth (RE) ions, the most useful systems are materials doped with $\mathrm{Er}^{3+}, \mathrm{Tm}^{3+}, \mathrm{Yb}^{3+}$, for example, crystals, glasses, ceramics or nanostructures [7-9]. Since the excitation of the UC luminescence in RE ions has a ladder nature (sequential absorption of excitation photons), non-radiative transitions from the intermediate energy levels are playing essential role in the efficiency of the whole process. To suppress the non-radiative losses and obtain higher quantum efficiency of the UC luminescence the host materials with low phonon energy are to be used. For this purpose, different binary and complex fluorides, including $\mathrm{CaF}_{2}$ [10], $\mathrm{BaF}_{2}$ [11], $\mathrm{LaF}_{3}$ [12], $\mathrm{BaYF}_{5}$ [13], $\mathrm{LiYF}_{4}$ [14], $\mathrm{NaYF}_{4}[15]$ doped with various optically active RE ions have been employed. 
Up to now, $\mathrm{NaYF}_{4}$ doped with $\mathrm{Yb}^{3+}, \mathrm{Er}^{3+}$ and $\mathrm{Tm}^{3+}$ has been considered as one of the most efficient materials for infrared radiation (at $\sim 1 \mu \mathrm{m})$ transformation into visible (blue, green and red) luminescence bands with possible applications including - and certainly not limited to - visualization of infrared radiation [16] and biomedical applications [17]. As a result of the increased interest towards this material, many papers related to different synthesis methods of $\mathrm{RE}$ doped $\mathrm{NaYF}_{4}$ and characterization of its spectroscopic properties have been published recently $[15,18-21]$.

Recent studies have shown that the efficiency of the UC luminescence in $\mathrm{NaLaF}_{4}: \mathrm{RE}$ could be comparable to that of $\mathrm{NaYF}_{4}: \mathrm{RE}$ [22-24]. However, up to now only few papers have reported some of the basic spectroscopic properties of $\mathrm{NaLaF}_{4}$ doped with $\mathrm{Er}^{3+}$ [22, 25-28].

The aim of the current work is to study the behaviour of the "green" photoluminescence $\left({ }^{4} \mathrm{~S}_{3 / 2} \rightarrow{ }^{4} \mathrm{I}_{15 / 2}\right)$ in $\mathrm{NaLaF}_{4}: \mathrm{Er}^{3+}$ at direct excitation. We will qualitatively explain the luminescence quenching that was experimentally observed as variations in the intensity and decay kinetics of the luminescence in $\mathrm{NaLaF}_{4}$ at different $\mathrm{Er}^{3+}$ concentrations. The obtained results might be useful for future studies of the UC processes in $\mathrm{NaLaF}_{4}: \mathrm{Er}^{3+}$ and similar materials.

\section{EXPERIMENTAL}

In this work, $\mathrm{Er}^{3+}$ doped $\mathrm{NaLaF}_{4}$ with different activator concentrations $0.2,1,2,4,10 \mathrm{~mol} \%$ ) was synthesized using the wet chemistry method. $\mathrm{La}_{2} \mathrm{O}_{3}$, $\mathrm{Er}_{2} \mathrm{O}_{3}$ were dissolved in hydrochloric acid yielding $\mathrm{LaCl}_{3}$ and $\mathrm{ErCl}_{3}$. After evaporation of liquid the chlorides were dissolved in deionised water, while in a separate beaker the water solution of $\mathrm{NaF}$ was prepared. Addition of this solution to the dissolved chlorides led to the $\mathrm{LaF}_{3}$ and $\mathrm{ErF}_{3}$ precipitation. The precipitate was washed several times with deionised water. Later, some amount of $\mathrm{NaF}$ was added to the precipitate and the solution was evaporated to dryness. Subsequently, the powder was annealed in $\mathrm{He}_{2} / \mathrm{F}_{2}$ gas flow at $600^{\circ} \mathrm{C}$ for $6 \mathrm{~h}$ to obtain polycrystalline (powder) $\mathrm{NaLaF}_{4}: \mathrm{Er}^{3+}$ material. Afterwards the powder was pressed to obtain tablets.

The structure of samples was checked by X-ray diffraction (XRD) analysis (XPert Pro MPD, $\mathrm{Cu}$ anode, operating at $40 \mathrm{kV} 30 \mathrm{~mA}$ ). Photoluminescence in the sample was excited by a pulsed solid-state laser NT342/3UV (pulse duration $\sim 4 \mathrm{~ns}$ ) from Ekspla (wavelength tunable from $210 \mathrm{~nm}$ to $2300 \mathrm{~nm}$ ). The spot size of $20 \mathrm{~mJ}$ laser beam on the sample was controlled by diaphragm and was in the order of $8 \mathrm{~mm}^{2}$. The luminescence decay kinetics was measured by an Andor SR-303i-B monochromator/spectrometer coupled to a photomultiplier tube (time resolution better than 10ns) and a Tektronix TDS 684A digital oscilloscope. The same spectrometer coupled to a CCD camera (Andor DU-401-BV) was used for studying the luminescence spectra.

Special care was taken at placing the sample tablets in the sample holder to achieve equal measurement conditions for all the samples. All measurements were performed at room temperature. 


\section{RESULTS AND DISCUSSION}

Sample characterization using XRD for $\mathrm{NaLaF}_{4}$ doped with different amount of $\mathrm{Er}^{3+}$ is shown in Fig. 1.

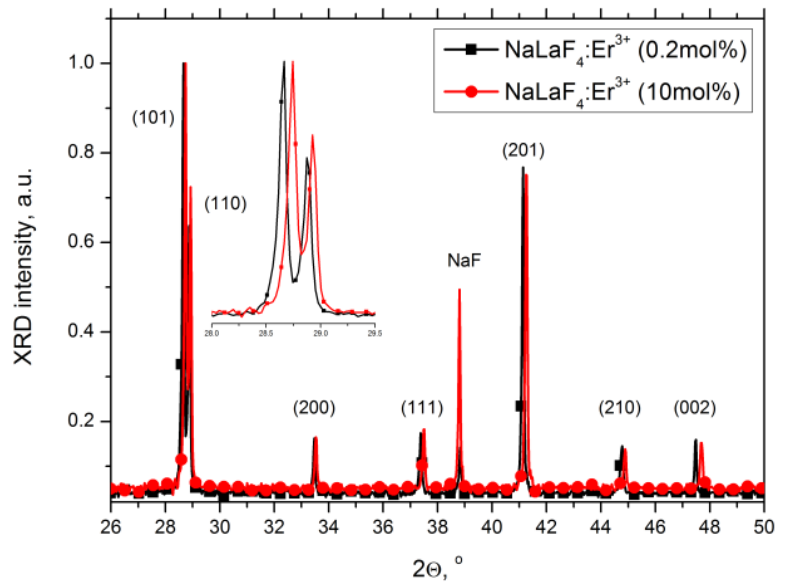

Fig. 1. XRD patterns measured for $\mathrm{NaLaF}_{4}: \mathrm{Er}^{3+}(0.2$ and $10 \mathrm{~mol} \%)$.

For small $\mathrm{Er}^{3+}$ ion concentrations mainly $\mathrm{NaLaF}_{4}$ diffraction peaks are observed. Some traces of $\mathrm{NaF}$ crystalline phase are also visible. When $\mathrm{Er}^{3+}$ concentration is increased, the peaks corresponding to $\mathrm{NaLaF}_{4}$ crystalline phase are shifted to higher angles (Fig. 1, inset), which could be explained by the difference in $\mathrm{La}^{3+}$ and $\mathrm{Er}^{3+}$ ionic radii. The radius of $\mathrm{Er}^{3+}(88 \mathrm{pm})$ is smaller than that of $\mathrm{La}^{3+}$ $(106 \mathrm{pm})$, which means that the incorporation of activator ions in $\mathrm{NaLaF}_{4}$ crystalline lattice would lead to a decrease in the lattice parameter of the latter, and the corresponding positions of XRD peaks would shift to higher degrees [22], which is observed experimentally (see Fig. 1, inset).

The luminescence spectrum for $\mathrm{NaLaF}_{4}: \mathrm{Er}^{3+}(0.2 \mathrm{~mol} \%)$ at $489 \mathrm{~nm}$ excitation reveals characteristic $\mathrm{Er}^{3+}$ luminescence bands in the green, red and IR spectral regions (Fig. 2), while the green band at about 540nm is dominating.

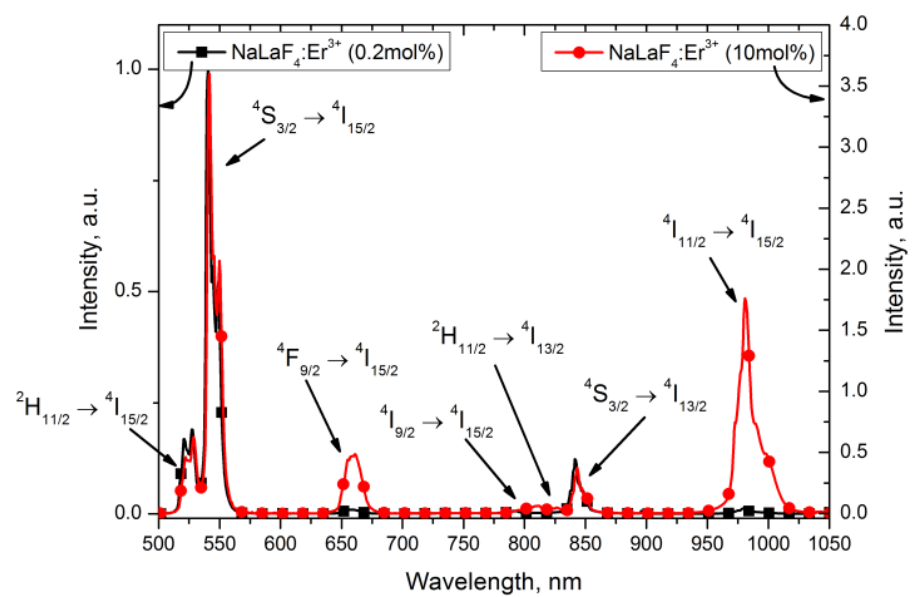

Fig. 2. Luminescence spectra for $\mathrm{NaLaF}_{4}: \mathrm{Er}^{3+}(0.2$ and $10 \mathrm{~mol} \%)$ excitation at $489 \mathrm{~nm}$. Spectra are normalized to the maximum intensity value. 
As the concentration of the activator is increased, the luminescence band positions and shapes do not vary. However, variations of the luminescence intensity are observed for the green $\left({ }^{4} \mathrm{~S}_{3 / 2} \rightarrow{ }^{4} \mathrm{I}_{15 / 2}\right)$, red $\left({ }^{4} \mathrm{~F}_{9 / 2} \rightarrow{ }^{4} \mathrm{I}_{15 / 2}\right)$ and IR $\left({ }^{4} \mathrm{I}_{11 / 2} \rightarrow{ }^{4} \mathrm{I}_{15 / 2}\right)$ bands. The dependence of the intensities on the $\mathrm{Er}^{3+}$ concentration is shown in Fig. 3. In order to show this more clearly, the luminescence band intensities are normalized to 1 for the lowest $\mathrm{Er}^{3+}$ concentration.

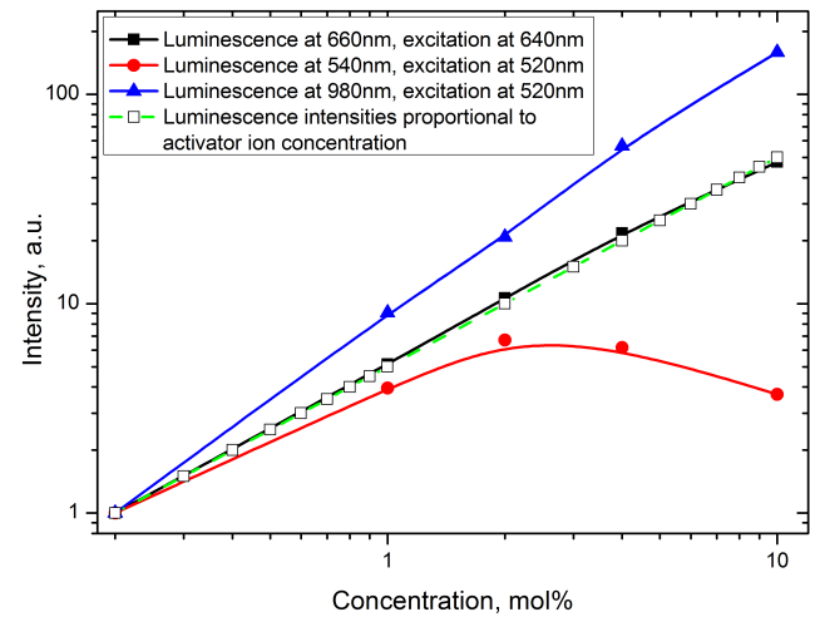

Fig. 3. Dependence of the intensity for some luminescence bands on $\mathrm{Er}^{3+}$ concentration in log-log scale. Dashed line represents luminescence intensity which should be proportional to the activator ion concentration.

It could be seen that the intensity of the red luminescence band is proportional to the activator concentration. Such behaviour is expected in the case of noninteracting activator ions when the increase in the number of activator ions is solely responsible for the luminescence intensity increase (dashed line in Fig. 3) [29]. The dependence of the green luminescence band intensity on the concentration is somewhat different: at lower $\mathrm{Er}^{3+}$ concentration the intensity increases but to a lesser degree as compared with the red luminescence band. The luminescence intensity reaches maximum at $\sim 2 \mathrm{~mol} \%$ of $\mathrm{Er}^{3+}$ concentration, and at higher $\mathrm{Er}^{3+}$ concentrations the luminescence intensity decreases. At the same time, the intensity of the $980 \mathrm{~nm}$ IR luminescence band excited at 520nm has a super-linear dependence on the concentration (the intensity increases $~ 160$ times while $\mathrm{Er}^{3+}$ concentration increases 50 times).

The decrease in the luminescence intensity at higher activator concentrations is usually attributed to the concentration quenching [30] when the rates of nonradiative transitions (migration, cross-relaxation, etc.) between the activator ions increase. The super-linear increase in intensity of the $980 \mathrm{~nm}$ lumenescence $\left({ }^{4} \mathrm{I}_{11 / 2} \rightarrow{ }^{4} \mathrm{I}_{15 / 2}\right)$ at higher activator concentrations could signify an involvement of some energy transfer mechanism responsible for the population of the ${ }^{4} \mathrm{I}_{11 / 2}$ level. This problem has been addressed in various works (e.g. [31]); in [32] several crossrelaxation (CR) processes in which ${ }^{4} \mathrm{~S}_{3 / 2}$ and ${ }^{4} \mathrm{I}_{11 / 2}$ levels are involved were proposed. 

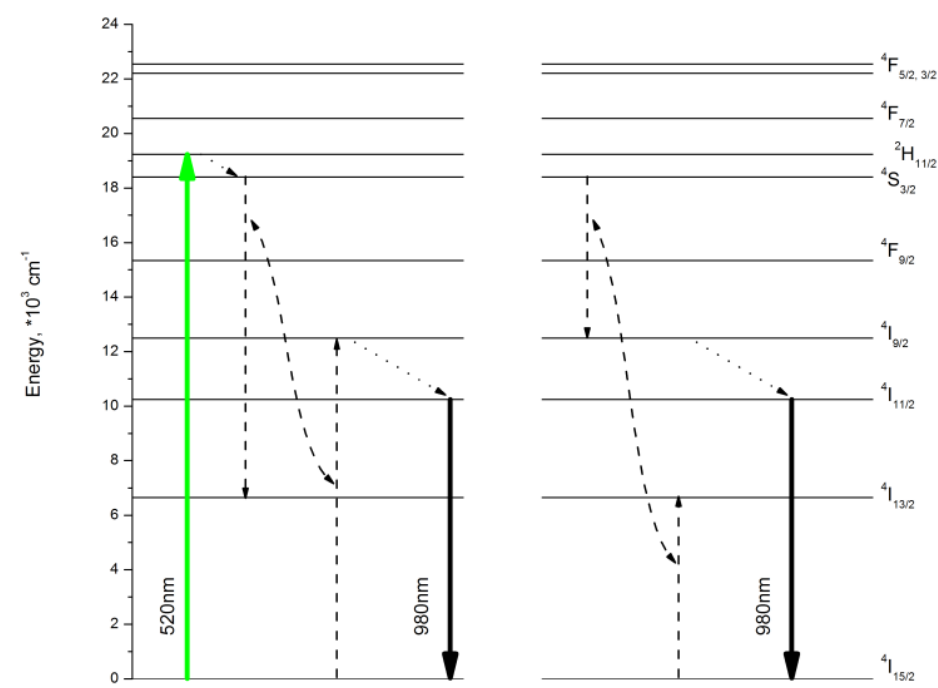

Fig. 4. Possible cross-relaxation processes in $\mathrm{Er}^{3+}$ : solid bold arrows - excitation and luminesscence, dashed arrows - energy transfer process, and doted arrows - non-radiative transition.

Some of possible CR processes $\left({ }^{4} \mathrm{~S}_{3 / 2} ;{ }^{4} \mathrm{I}_{15 / 2}\right) \rightarrow\left({ }^{4} \mathrm{I}_{13 / 2} ;{ }^{4} \mathrm{I}_{9 / 2}\right)$ and $\left({ }^{4} \mathrm{~S}_{3 / 2}\right.$; $\left.{ }^{4} \mathrm{I}_{15 / 2}\right) \rightarrow\left({ }^{4} \mathrm{I}_{9 / 2} ;{ }^{4} \mathrm{I}_{13 / 2}\right)$ shown in Fig. 4 seem to be most probable in our case. In the first case, the energy from ${ }^{4} \mathrm{~S}_{3 / 2} \rightarrow{ }^{4} \mathrm{I}_{13 / 2}$ transition is transferred to the neighboring $\mathrm{Er}^{3+}$ and electron from ${ }^{4} \mathrm{I}_{15 / 2}$ (ground state) is excited to ${ }^{4} \mathrm{I}_{9 / 2}$. In the second case, the electron from ${ }^{4} \mathrm{~S}_{3 / 2}$ relaxes to ${ }^{4} \mathrm{I}_{9 / 2}$ and the energy is transferred to other $\mathrm{Er}^{3+}$ where electron from ${ }^{4} \mathrm{I}_{15 / 2}$ is excited to ${ }^{4} \mathrm{I}_{9 / 2}$. In both these CR processes the initial state is ${ }^{4} \mathrm{~S}_{3 / 2}$ and the final states are ${ }^{4} \mathrm{I}_{13 / 2} ;{ }^{4} \mathrm{I}_{9 / 2}$. After reaching the ${ }^{4} \mathrm{I}_{9 / 2}$ energy level, $\mathrm{Er}^{3+}$ in nonradiative way relaxes to the ${ }^{4} \mathrm{I}_{11 / 2}$ energy level, and the IR luminescence at $980 \mathrm{~nm}$ is observed. Obviously, in the mentioned CR processes the intensity of the green luminescence band would decrease due to depopulation of ${ }^{4} \mathrm{~S}_{3 / 2}$ energy level, while the intensity of the $980 \mathrm{~nm}$ band would increase as shown in Fig. 3 .

This assumption about $\mathrm{CR}$ processes is confirmed by the luminescence decay kinetics: in Fig. 5 the kinetics of red and green luminescence bands measured under direct excitation are shown for $\mathrm{NaLaF}_{4}$ with different $\mathrm{Er}^{3+}$ concentration.

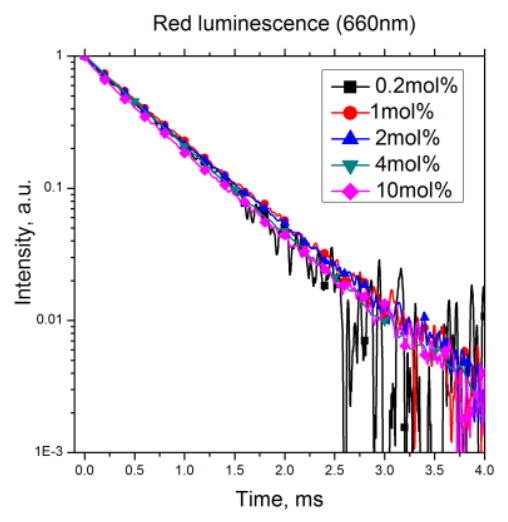

a

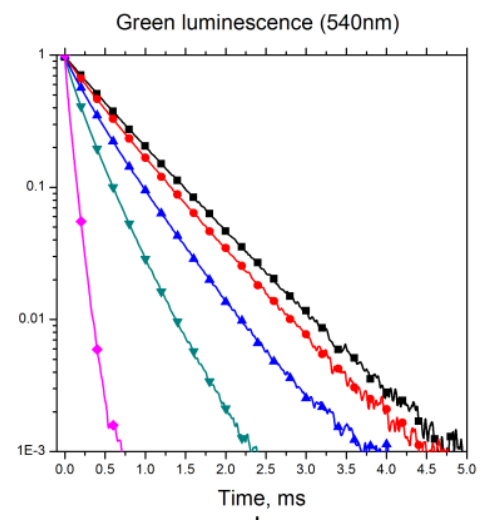

b

Fig. 5. Decay profiles (log scale) for the ${ }^{4} \mathrm{~F}_{9 / 2} \rightarrow{ }^{4} \mathrm{I}_{15 / 2}$ (a) and ${ }^{4} \mathrm{~S}_{3 / 2} \rightarrow{ }^{4} \mathrm{I}_{15 / 2}$ (b) optical transition in $\mathrm{NaLaF}_{4}$ at different $\mathrm{Er}^{3+}$ concentrations; excitation at $650 \mathrm{~nm}$ (a) and 520nm (b). 
For the given $\mathrm{Er}^{3+}$ concentration range the red luminescence decay kinetics (Fig. 5a) maintains the same profile and has a simple exponential nature. This indicates that there are no energy transfer processes (concentration quenching) which depopulated ${ }^{4} \mathrm{~F}_{9 / 2}$ energy level under direct excitation.

The situation is somewhat different for the green luminescence decay kinetics shown in Fig. $5 b$. For smaller $\mathrm{Er}^{3+}$ concentration this kinetics has a simple exponent nature. $\mathrm{As}^{\mathrm{Er}^{3+}}$ concentration is increased, the decay kinetics of green luminescence becomes faster, and its nature is no longer simple exponential.

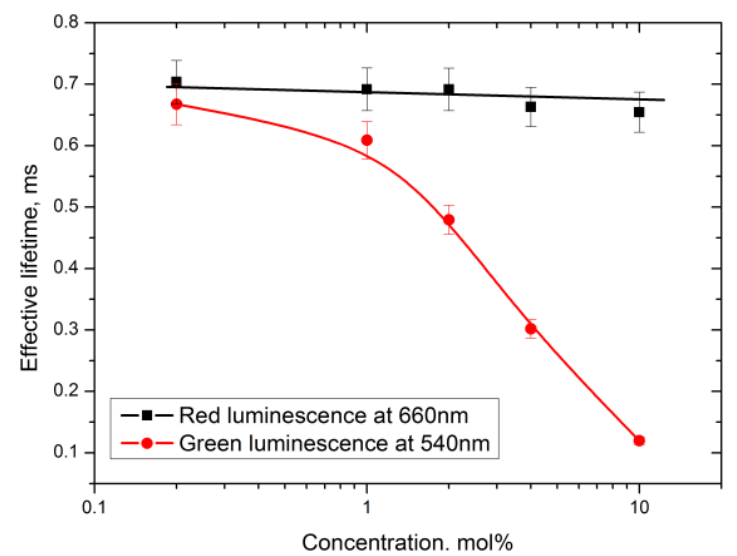

Fig. 6. Effective lifetime for the red and green luminescence decay kinetics under direct excitation.

Such luminescence decay kinetics is characterized with effective lifetime $\tau_{\text {eff }}[33]:$

$$
\tau_{\text {eff }}=\frac{\int t \cdot I(t) d t}{\int I(t) d t}
$$

where $I(t)$ is the luminescence intensity at time moment $t$. Figure 6 shows comparison of effective lifetime obtained for the green and red luminescence decay kinetics. For the red luminescence band the effective lifetime only slightly varies over the given $\mathrm{Er}^{3+}$ concentration range. In the green luminescence band a small decrease in the effective lifetime is observed for the sample with low $\mathrm{Er}^{3+}$ concentration $(0.2-1 \mathrm{~mol} \%)$. At higher $\mathrm{Er}^{3+}$ concentrations a considerable decrease in the effective lifetime is observed. The decrease in the lifetime and the non-exponential nature of the green luminescence decay kinetics correlates well with the intensity change of the green and IR bands (Fig.3) and support the previous assumption about the concentration quenching of green band due to $\mathrm{CR}$ processes.

\section{CONCLUSIONS}

The conclusions drawn from the results of measuring the photoluminescence spectra and luminescence decay kinetics of $\mathrm{NaLaF}_{4}$ doped with Er ions in different concentration are as follows.

1. The maximum intensity of the green luminescence band is for $\mathrm{Er}^{3+}$ concentration of $2 \mathrm{~mol} \%$. 
2. At higher $\mathrm{Er}^{3+}$ concentrations considerable quenching of the green luminescence occurs. This quenching is attributed to a cross-relaxation process which depopulates the ${ }^{4} \mathrm{~S}_{3 / 2}$ energy level and populates the ${ }^{4} \mathrm{I}_{11 / 2}$ energy level.

3. No concentration quenching was observed for the red luminescence.

The obtained results will be useful for further studies of the up-conversion mechanisms in $\mathrm{NaLaF}_{4}: \mathrm{Er}^{3+}$ and similar materials.

\section{ACKNOWLEDGEMENTS}

This work has been supported by the European Social Fund within the project "Support for Doctoral Studies at University of Latvia" (No. 2009/0138/1DP/1.1.2.1.2/09/IPIA/VIAA/004) as well as National Research Programme IMIS (project 1).

\section{REFERENCES}

1. Auzel, F. (2004). Upconversion and anti-Stokes processes with $f$ and $d$ ions in solids. Chem. Rev., 104, 139-174. DOI: 10.1021/cr020357g

2. Tong, F., Risk, W.P., Macfarlane, R.M. \& Lenth, W. (1989). $551 \mathrm{~nm}$ diode-laserpumped upconversion laser. Electron. Lett., 25, 1389-1391. DOI: 10.1049/el:19890930

3. Dong, B., Yang, T., \& Lei, M.K. (2007). Optical high temperature sensor based on green up-conversion emissions in $\mathrm{Er}^{3+}$ doped $\mathrm{Al}_{2} \mathrm{O}_{3}$. Sens. Actuators, $B$ 123, 667-670. DOI: 10.1016/j.snb.2006.10.002

4. Grube, J., Doke, G., Voss, M., Sarakovskis, A. \& Springis, M. (2011). Multicolor upconversion luminescence in rare-earth doped $\mathrm{NaLaF}_{4}$. IOP Conf. Ser.: Mater. Sci. Eng., 23, 012004. DOI: 10.1088/1757-899X/23/1/012004

5. Silva, J.E.C., de Sa, G.F. \& Santa-Cruz, P.A. (2001). Red, green and blue light generation in fluoride glasses controlled by double excitation. J. Alloys Compd., 323-324, 336-339. DOI: 10.1016/S0925-8388(01)01033-7

6. Shalav, A., Richards, B.S. \& Green, M.A. (2007). Luminescent layers for enhanced silicon solar cell performance: up-conversion. Sol. Energy Mater. Sol. Cells, 91 (9), 829-842. DOI: 10.1016/j.solmat.2007.02.007

7. Riedener, T., Egger, P., Hulliger, J., \& Gudel, H.U. (1997). Upconversion mechanisms in $\mathrm{Er}^{3+}$-doped $\mathrm{Ba}_{2} \mathrm{YCl}_{7}$. Phys. Rev. B, 56, 1800-1808. DOI: 10.1103/PhysRevB.56.1800

8. Ferber, S., Gaebler, V., \& Eichler, H.-J. (2002). Violet and blue upconversion-emission from erbium-doped ZBLAN-fibers with red diode laser pumping. Opt. Mater., 20 (3), 211-215. DOI: 10.1016/S0925-3467(02)00064-2

9. Kishi, Y., \& Tanabe, S. (2006). Infrared-to-visible upconversion of rare-earth doped glass ceramics containing $\mathrm{CaF}_{2}$ crystals. J. Alloys Compd. 408-412, 842-844. DOI: $10.1016 /$ j.jallcom.2005.01.096

10. Chen, D., Wang, Y., Ma, E., Yu, Y., Liu, F. (2007). Partition, luminescence and energy transfer of $\mathrm{Er}^{3+} / \mathrm{Yb}^{3+}$ ions in oxyfluoride glass ceramic containing $\mathrm{CaF}_{2}$ nano-crystals. Opt. Mater. 29 (12), 1693-1699. DOI: 10.1016/j.optmat.2006.09.002

11. Orlovskii, Yu. V., Basiev, T.T., Pukhov, K.K., Vorobiev, I.N., Papashvili, A.G., Pelle, F. \& Osiko, V.V. (2001). Multiphonon relaxation of mid-IR transitions of rare-earth ions in the crystals with fluorite structure. J. Lumin., 94-95, 791-795. DOI: $10.1016 / \mathrm{S} 0022-2313(01) 00372-6$

12. Yanes, A.C., Del-Castillo, J., Mendez-Ramos, J., Rodriguez, V.D., Torres, M.E. \& Arbiol, J. (2007). Luminescence and structural characterization of transparent nanostructured $\mathrm{Eu}^{3+}$-doped $\mathrm{LaF}_{3}-\mathrm{SiO}_{2}$ glass-ceramics prepared by sol-gel method. Opt. Mater. 29 (8), 999-1003. DOI: 10.1016/j.optmat.2006.02.021 
13. Sun, J., Xian, J., \& Du, H., (2011). Hydrothermal synthesis of $\mathrm{BaYF}_{5}: \mathrm{Yb}^{3+} / \mathrm{Er}^{3+}$ upconversion luminescence submicrospheres by a surfactant-free aqueous solution route. J. Phys. Chem. Solids 72 (3), 207-103. DOI: 10.1016/j.jpcs.2010.12.013

14. Malinowski, M., Jacquier, B., Bouazaoui, M., Joubert, M., \& Linares, C. (1990). Laser-induced fluorescence and up-conversion processes in $\mathrm{LiYF}_{4}: \mathrm{Nd}^{3+}$ laser crystals. Phys. Rev. B 41, 31-40. DOI: 10.1103/PhysRevB.41.31

15. Wei, Y., Lu, F., Zhang, X. \& Chen, D. (2008). Polyol-mediated synthesis and luminescence of lanthanide-doped $\mathrm{NaYF}_{4}$ nanocrystal upconversion phosphors. J. Alloys Compd., 455 (1-2), 376-384. DOI: 10.1016/j.jallcom.2007.01.107

16. Tokin IR Catcher; Tokin America (155 Nicholson Lane, San Jose, CA, 95134), 1987.

17. Suyver, F., Aebischer, A., Biner, D., Gerner, P., Grimm, J., Heer, S., Kramer, K.W., Reinhard, C. \& Gudel, H.U. (2005). Novel materials doped with trivalent lanthanides and transition metal ions showing near-infrared to visible photon upconversion. Opt. Mater., 27 (6), 1111-1130. DOI: 10.1016/j.optmat.2004.10.021

18. Kramer, K.W., Biner, D., Frei, G., Gudel, H.U., Hehlen, M.P., \& Luthi, S.R. (2004). Hexagonal Sodium Yttrium Fluoride Based Green and Blue Emitting Upconversion Phosphors. Chem. Mater. 16 (7), 1244-1251. DOI: 10.1021/cm031124o

19. Liu, F., Wang, Y., Chen, D. \& Yu, Y. (2007). Investigation on crystallization kinetics and microstructure of novel transparent glass ceramics containing $\mathrm{Nd}: \mathrm{NaYF}_{4}$ nanocrystals. Mater. Sci. Eng. B, 136 (2-3), 106-110. DOI: 0.1016/j.mseb.2006.09.012

20. Yanes, A.C., Santana-Alonso, A., Mendez-Ramos, J., del-Castillo, J., Rodriguez, V.D. (2009). $\mathrm{Yb}^{3+}-\mathrm{Er}^{3+}$ co-doped sol-gel transparent nano-glass-ceramics containing $\mathrm{NaYF}_{4}$ nanocrystals for tuneable up-conversion phosphors. J. Alloys Compd., 480 (2), 706-710. DOI: 10.1016/j.jallcom.2009.02.019

21. Li, J.J., Yang, L.W. Zhang, Y.Y., Zhong, J.X., Sun, C. Q., \& Chuc, P. K. (2011). Pump-power tunable white upconversion emission in lanthanide-doped hexagonal $\mathrm{NaYF}_{4}$ nanorods. Opt. Mater., 33 (6), 882-887. DOI: 10.1016/j.optmat.2011.01.016

22. Sarakovskis, A., Grube, J., Mishnev, A., \& Springis, M. (2009). Up-conversion processes in $\mathrm{NaLaF}_{4}: \mathrm{Er}^{3+}$. Opt. Mater., 31 (10), 1517-1524. DOI: 10.1016/j.optmat.2009.02.015

23. de Pablos-Martín, A., Ramírez, M.O., Durán, A., Bausá, L.E., \& Pascual, M.J. (2010). $\mathrm{Tm}^{3+}$-doped oxy-fluoride glass-ceramics containing $\mathrm{NaLaF}_{4}$ nano-crystals. Opt. Mater., 33 (2), 180-185. DOI: 10.1016/j.optmat.2010.08.004

24. Tyagi, N., Reddy, A.A., \& Nagarajan, R. (2010). $\mathrm{KLaF}_{4}: \mathrm{Er}$ an efficient upconversion phosphor. Opt. Mater., 33 (1), 42-47. DOI: 10.1016/j.optmat.2010.07.014

25. Sarakovskis, A., Voss, M., Doke, G., Grube, J., \& Springis, M. (2011). Novel synthesis of up-conversion phosphor based on rare-earth doped $\mathrm{NaLaF}_{4}$. IOP Conf. Ser.: Mater. Sci. Eng., 23, 012003. DOI: 10.1088/1757-899X/23/1/012003

26. Kano, T., Yamamoto, H., \& Otomo, Y. (1972). NaLnF 4 : $\mathrm{Yb}^{3+}, \mathrm{Er}^{3+}$ (Ln:Y,Gd,La): Efficient Green-Emitting Infrared-Excited Phosphors. J. Electrochem. Soc., 119 (11), 1561-1564. DOI: 10.1149/1.2404042

27. Krumpel, A.H., van der Kolk, E., Zeelenberg, D., Bos, A.J.J., Krämer, K.W. \& Dorenbos, P. (2008). Lanthanide 4f-level location in lanthanide doped and ceriumlanthanide codoped $\mathrm{NaLaF}_{4}$ by photo- and thermoluminescence J. Appl. Phys., 104, 073505. DOI: 10.1063/1.2955776

28. Yi, G.S., Lee, W.B. \& Chow, G.M. (2007). Synthesis of $\mathrm{LiYF}_{4}, \mathrm{BaYF}_{5}$, and $\mathrm{NaLaF}_{4}$ optical nanocrystals. J. Nanosci. Nanotechnol., 7, 2790-2794. DOI: $10.1166 /$ jnn.2007.638

29. Tkachuk, A.M., Klokishner, S.I., \& Petrov, M.V. (1985). Самотушение люминесценции в концентрированных кристаллах двойных фторидов литияэрбия и лития-гольмия Opt. Spectrosc., 59, 802-811 (in Russian).

30. Yen, W. M., Shionoya, S., \& Yamamoto, H. (2006). Phosphor Handbook. CRC Press (USA). 
31. Luthi, S.R., Pollnau, M., Gudel, H.U., \& Hehlen, M.P. (1999). Near-infrared to visible upconversion in $\mathrm{Er}^{3+}$-doped $\mathrm{Cs}_{3} \mathrm{Lu}_{2} \mathrm{Cl}_{9}, \mathrm{Cs}_{3} \mathrm{Lu}_{2} \mathrm{Br}_{9}$, and $\mathrm{Cs}_{3} \mathrm{Y}_{2} \mathrm{I}_{9}$ excited at $1.54 \mu \mathrm{m}$. Phys. Rev. B, 60, 162-178. DOI: 10.1103/PhysRevB.60.162

32. Tkachuk, A.M., Ivanova, S.E., Joubert, M.-F., Guyot, Y., \& Gapontzev, V.P. (2004). Population of excited erbium levels in $\mathrm{Er}^{3+}: \mathrm{Na}_{0.4} \mathrm{Y}_{0.6} \mathrm{~F}_{2.2}$ (Er:NYF) laser crystals. J. Alloys Compd., 380 (1-2), 130-135. DOI: 10.1016/j.jallcom.2004.03.038

33. Nakazawa, E. (1999). In: Phosphor Handbook; Shionoya S, Yen W M, Eds. Boca Raton (FL): CRC Press.

\section{KONCENTRĀCIJAS IETEKME UZ Er $^{3+}$ LUMINISCENCI $\mathrm{NaLaF}_{4}$ MATRICĀ}

J Grūbe, A. Šarakovskis, G. Doķe, M. Springigis

Kopsavilkums

Darbā pētīta $\mathrm{Er}^{3+}$ fotoluminiscences atkarība no $\mathrm{Er}^{3+}$ koncentrācijas $\mathrm{NaLaF}_{4}$ matricā. Pieaugot $\mathrm{Er}^{3+}$ koncentrācijai līdz $2 \mathrm{~mol} \%$ luminiscences intensitātes raksturīgajām $\mathrm{Er}^{3+}$ joslām zaļā $(540 \mathrm{~nm})$, sarkanā $(660 \mathrm{~nm})$ un infrasarkanajā (980 nm) spektra apgabalā pieaug. Pie $\mathrm{Er}^{3+}$ koncentrācijas virs $2 \mathrm{~mol} \%$ novērojama izteikta zal̦ās luminiscences koncentrācijas dzēšana un virslineārs infrasarkanās luminiscences joslas pieaugums, kas saistīts ar kross-relaksācijas procesiem starp aktivatora joniem.

24.02.2014. 